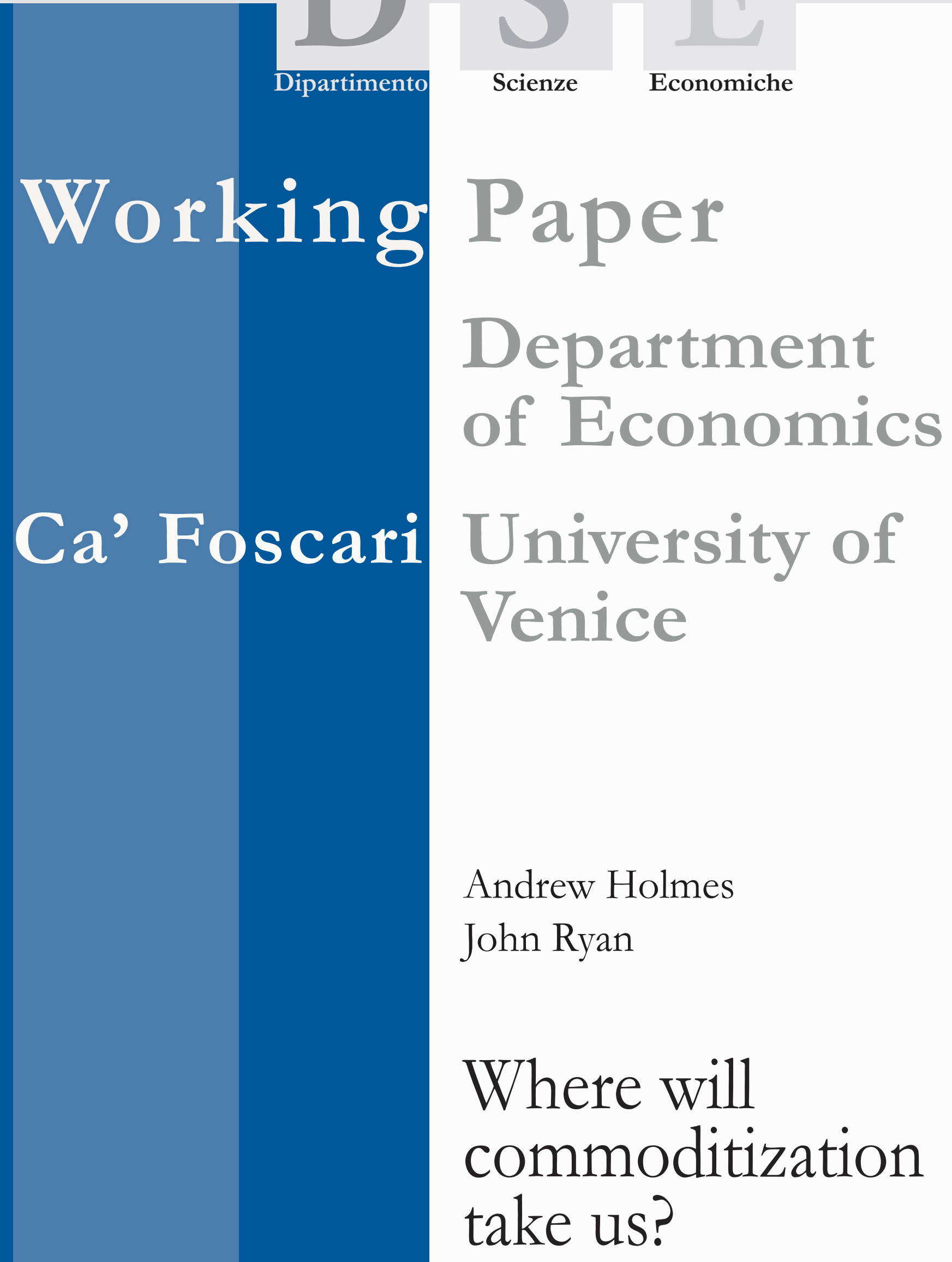




\title{
Where will commoditization take us?
}

\author{
Andrew Holmes \\ Partner, Paricint \\ John Ryan \\ Hult International Business School, CEPA research fellow
}

First Draft: September 2008

\begin{abstract}
Predicting the future is an imprecise science, and something that should always be carried out carefully and the results should be taken with a pinch of salt. That said it is sensible to assume that most of the drivers of commoditization are likely to remain in force for the foreseeable future. Unlike the futurologists who attempt to predict how society and technology will change over the next fifty years, we are only going to look a few years ahead, which is a more sensible time horizon. History is not always a good predictor of the future, but in the case of commoditization we think it is. It is clear that when we look back in time we can see how the process of commoditization has subsumed great tranches of industry, eliminated significant numbers of manual labourers and increased the general efficiency and effectiveness of society. In many respects we could argue that it was important to the advancement of the industrialised economies of the West. In projecting forward from this point, we should expect commoditization to continue to expand its footprint into areas which we currently think are outside of the realms of possibility. After all, no one would have expected the IT industry to have become so commoditized when it first emerged during the 1940s. And in the same way that white collar workers were caught out when they believed they were immune from the initial waves of downsizing and offshoring that affected the manufacturing sector, others at the mid- and high-end of the workforce may also be caught out sometime in the future. And as commoditization continues to advance it will touch on many more peoples' lives and livelihoods.
\end{abstract}

\section{Keywords}

Commoditization, Offshoring, Talent, Technology, Competition, Inequality

\section{JEL Codes}

A10, D21, D23, D24, D40, F02

Address for correspondence:

John Ryan

Flat 7, 307 Upper Richmond Road, London SW15 6SS

England

Phone: (++44) 7951765549

jmtryan@aol.com

This Working Paper is published under the auspices of the Department of Economics of the Ca' Foscari University of Venice. Opinions expressed herein are those of the authors and not those of the Department. The Working Paper series is designed to divulge preliminary or incomplete work, circulated to favour discussion and comments. Citation of this paper should consider its provisional characte

The Working Paper Series is availble only on line (www.dse.unive.it/pubblicazioni) For editorial correspondence, please contact: wp.dse@unive.it
Department of Economic

Ca' Foscari University of Venice

Cannaregio 873, Fondamenta San Giobbe

30121 Venice Italy

Fax: ++390412349210 


\section{Introduction}

When we look into the future and how commoditization might play out we can see a variety of potential changes in the nature of work and employment and in some of the wider processes which govern and define society. For the purposes of this brief peak into the future, we will focus on:

- Technology and how it will continue to eliminate work at the low, mid and high end of the employment spectrum

- The emergence of the extreme worker at one end and the disenfranchised jobber at the other and the inevitable rise of a wider labour war which will no longer be focused on just the most talented in society

- The widening gap between the winners and losers within the workplace and the impact the subsequent inequality in income has on the health and wellbeing of all concerned

- The emergence of a vicious cycle which may be impossible (for most of us) to break out of

- The rise of protectionist behaviour to combat the worst impacts of commoditization.

There may of course be a number of other changes which could be less or more significant than those we are about to explore. Some of them might be disruptive and unpredictable, but in the end we can only see what the future holds once it arrives. What we can do however, is to prepare for it as much as we can.

\section{Technology - squeezing work at every level}

There can be little doubt that the micro chip will continue to advance and this is likely to allow activity which currently requires high-touch or significant intelligence and brain power to complete to become subsumed within the next generations of computer systems. The recent launch of Nvidia's GeForce 8800 chip is perhaps just the beginning. Nvidia invested over $\$ 400$ million and four years perfecting the chip, which involved a fundamental redesign of the circuitry so that instead of handling one task at a time, it is now capable of handling more varied and parallel jobs. The launch of the new chip was accompanied by an image of an actress which was so lifelike that it looked as though it had been generated by a camera not a computer. Capturing the image involved gluing reflective dots over the actress' body and taking hundreds of pictures of her movements (which took some five hours to complete). The result was however dramatic, in that it was possible to see her shoulder blades move beneath her skin, facial expressions and even individual pores on her face. Apart from the obvious application within the gaming industry, Nvidia believes the GeForce 8800 will be used in special purpose computing applications and accelerator devices to take on jobs such as weather forecasting, financial simulations and rendering images from medical scanning equipment and more importantly open up a whole new class of computing. 
The capability of chip technology continues to advance at such a progressive rate that we should expect the GeForce chip to be surpassed in the not too distant future even though it has around 681 million transistors packed onto its surface; double the number on the current generation of chips and significantly more than Intel's Core 2 Duo Microprocessor which has only 291 million $^{1}$. And it seems that this not too distant future is already upon us with the announcement from Intel and IBM that they have made possibly the biggest and most significant breakthrough in chip technology in 40 years. Both claim that Hafnium, a metal used in the manufacture of nuclear reactors, could soon replace the silicon chip and with it, its limitations on power and speed $^{2}$. Intel believes that it will be possible to double the density of transistors packed onto the chip thereby making computers more powerful, faster and reducing the cost of powering the transistors by one third ${ }^{3}$. We have yet to feel the full impact of this or indeed the future generation of microprocessors that will inevitably follow over the coming years, but even now the reality of avatars replacing actors and newsreaders is fast becoming a reality. Such high-touch employment could go the same way as the typing pool and we may not require the services of the highly paid newscasters reading from an autocue for much longer.

Although it might take time before high-end work is fully commoditized, the same cannot be said of the mid and low end activities of the workplace. In fact we should expect the routine work undertaken by the average white collar worker to be squeezed out of existence, or reduced to the bare minimum required to ensure that people are on hand to deal with the occasional crisis. This process of commoditization is being driven by a combination of process standardization, improved interconnectivity between IT applications and the availability of a cheaper workforce overseas. Although standardising process and having a cheap and capable labour force are important, key to the changes we are witnessing is the capability of technology, as without effective and connected systems it would be almost impossible to move any work offshore or take advantage of the capabilities of workers from different geographies. The relationship between technology and the elimination and offshoring of work is also circular; as technologies improve through the intellectual efforts applied by those that develop and advance them, it becomes easier to move the location of that labour to other locations across the world, something not lost on the IT industry. Moreover, as technology improves it leads to a greater instability in the working environment and increases the level of uncertainty for both physical labour (as we witnessed in the Industrial Revolution and more recently with the manufacturing sector) and knowledge based labour (as we started to see in the 1990s and of course now $)^{4}$.

Today it is possible for the transactional activities of an organization to be performed by technology and moved to outsource service providers and increasingly offshore. Over time the focus of technology will shift away from the most obvious targets associated with transactional activity to first the removal of process intensive activities and finally to the non-critical decision making activities which can be aided by effective data mining and business intelligence software (figure 1). The embedded intelligence within technology is creating smart systems that over time will become

\footnotetext{
${ }^{1}$ Clark, D., (2006), Nvidia’s powerful chip moves closer to 'reality’, Technology Journal, The Wall Street Journal, November 9, p B3

${ }^{2}$ Walsh, D., (2007) Computers ready to break speed limit in Hafnium valley, January 29, Timesonline, www.timesonline.co.uk

${ }^{3}$ Ibid.

${ }^{4}$ Betancourt, M., (2004) Labour/Commodity/Automation A response to "The digital death rattle of the American middle class: a cautionary tale, ctheory.net, p11
} 
more efficient and cost effective in eliminating the low end activities which are narrowly defined such as customer support (queries, order processing etc.).

The logical extension of the continued improvements in technology is for all labour to become a commodity. In the same way that blue collar labour has become commoditized and offshored, white collar work will become a commodity as organizations continually shift labour from country to country in order to exploit the differences in labour costs ${ }^{5}$. The smarter technology becomes the higher up the food chain commoditization goes. And as long as we have scientists and technologists pushing the envelope of technology, this process will continue. For example in approximately five years from now, computers will be able to read and tag the news stories and information emanating from the myriad of newspapers and agencies across the globe. So what you might ask, but this is the same information that is currently used by the highly paid traders in the stock exchanges throughout the world and if this technology is as good as they believe it will be it could potentially make them obsolete, saving their employers literally billions in salaries, bonuses and share options. In a commoditized world, anyone whose job is defined by or involves a significant use of computers is at risk of downward mobility ${ }^{6}$.

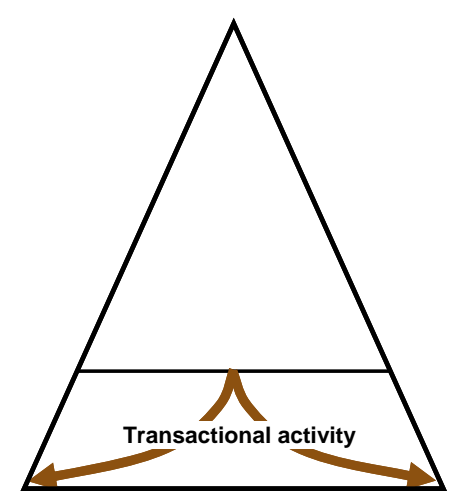

Now

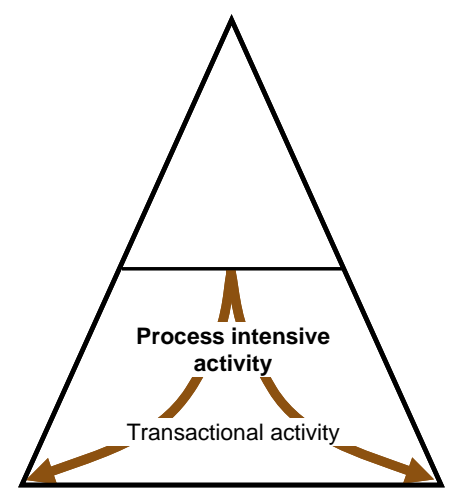

Next

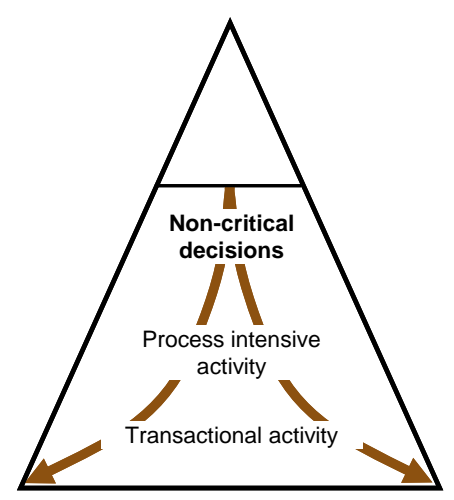

Future

Figure 1 The shifting focus of technology

Where it will end is a question that is on an increasing number of workers' lips and surely there will be some work that can avoid the commoditization trap. Work which requires innovation and high intellect may be safe as removing this from the core of the organization may be a step too far. But this will not stop companies from attempting to reduce the reliance on expensive resources and eliminating the need for human contact through the use of new technologies; it's inevitable in an increasingly commoditized economy. And this is already happening. For example, Proctor \& Gamble (P\&G) is currently employing cave technology to accelerate their market research. The technology allows $P \& G$ to create a virtual reality store in which their clients and customers can walk through and explore their products. The cave recreates the stores of their customers, such as Tesco, Sainsbury and Boots, in every detail and provides an environment in which customers and clients can walk through the store, handle the merchandise and even buy products. P\&G is using the reactions of customers to test alternative store layouts, displays and packaging. The cave allows them to dramatically accelerate the pace of innovation and cut costs whilst working to

\footnotetext{
${ }^{5}$ Betancourt, M., (2004) Labour/Commodity/Automation A response to "The digital death rattle of the American middle class: a cautionary tale, ctheory.net, $\mathrm{p} 7$

${ }^{6}$ Hacker, J., (2006), The great risk shift, (Oxford: Oxford University Press), p 78
} 
win over powerful retail clients. The process which can take up to two years to complete and is often fraught with difficulties can be completed within three months. We can only speculate what this might mean for the armies of skilled market research professionals, but if history is anything to go by, the writing might be on the wall for the majority ${ }^{7}$.

\section{The extreme worker and the war for labour}

There are a few books which discuss in some considerable detail why employees leave their jobs and what employers should be doing to retain their best staff. As time marches on, the local pools of talented staff on which organizations depend are expected to dry up because of the aging of the population and the constraints (political, as well as physical) imposed on immigrant labour. For those with the skills in demand the future is bright and it may not be long before we begin to see job auctions emerging in which the most talented in society open themselves up to the highest bidder ${ }^{8}$. Indeed we are already witnessing the growth in the income share which is accruing to the top 0.1 per cent of workers. According to the OECD this reflects the effects of globalisation which is creating opportunities for a small elite cohort of workers ${ }^{9}$. Being the most talented will bring some very high rewards, which for some can mean calling the shots and enjoying a lifestyle that will be increasingly out of reach for the majority. But at a personal level such high incomes won't come cheaply. Extreme jobs in which employees are required to work exceptionally long hours whilst juggling immense and conflicting responsibilities in order to both justify their high incomes and to service their global clients may not be new. After all we all know of workaholics who will literally sacrifice their entire life for their career, but such jobs may well become the norm for those with talent who wish to stay on top of the career ladder. And if you think this is bad, just consider the lengths many middle class people will go to, to ensure their offspring end up in these positions. In China parents are able to send their very young children to the Early MBA programme, an American-inspired course for three to six year olds, described as 'enrichment education for tomorrow's leaders'. The subjects taught to these toddlers (after all that is what they are) include mathematics, economics, astronomy and team-building ${ }^{10}$. Forcing children into a pattern of work at such an early age is nothing short of insane, but the sad truth is that such courses and parental pressure will probably increase over the next decade or so as the intensity of competition for top jobs increases. In a similar vein, competition among graduates for jobs is already so fierce that career coaches have started to emerge who charge up to $£ 5,000$ to help those willing to pay a step onto the career ladder ${ }^{11}$. With three graduates chasing each graduate-level job, it is no longer enough to have a good degree, and as graduates and their parents become more desperate to secure good jobs, such services are likely to be in high demand. Cynical though the purveyors of such advice are and although success cannot be guaranteed, it is likely that their ranks will increase over time. At least with greater numbers their services will become commoditized, so the $£ 5,000$ charged today will undoubtedly drop.

\footnotetext{
${ }^{7}$ Mitchell, A., (2006), P\&G takes shoppers to another world in war of the brands, Financial Times, October 18, p 18.

${ }^{8}$ Canton, J., (2006), The Extreme Future, (New York: Dutton), pp 97-98.

${ }^{9}$ OECD (2007), Employment outlook, p 117

${ }^{10}$ James, O., (2007), Affluenza, (London: Random House), pp 192-194

${ }^{11}$ Griffiths, S., (2007), The price of your first break, The Sunday Times, July, 8, p4-13
} 
Extreme jobs may entail 100 plus hour work weeks often spanning the weekends. We see this today within the investment banking community. Fresh-faced graduates enter their banking career by putting in 100 plus hour weeks for at least 24 months ${ }^{12}$. The same is true of the legal profession, which continues to be associated with gruelling schedules, fairly dull work and little work life balance ${ }^{13}$. Some of the reasons why we will see an increasing number of extreme jobs include ${ }^{14}$ :

- The intensification of competition. Over time the number of promotion opportunities for staff will diminish as hierarchies flatten the impact of mergers and acquisitions eliminate senior roles, as new workers (often immigrants) join the workforces who are willing to put in inhuman hours to get on and work is offshored to save costs.

- The cult of the extreme. It can be very difficult for executives to demonstrate their worth to themselves or those around them without some outward evidence of their long hours, much of which remains invisible. So in order to increase the visibility of the sacrifice they make, the extreme worker is increasingly being equated to sports superstars; investment bankers will brag about the deal they have just pulled off against all the odds and at massive personal cost in the same way a base jumper will after they have completed a particularly dangerous leap.

- Technology is a significant factor in the intensification of work. Increased connectivity between client and service provider and boss and subordinate means that those in extreme positions will rarely escape the office. In fact they will become the office, always accessible no matter where they are or what time of day it is

- Work replacing home as the new social centre. The loss of social capital because of the increasing hours spent in the office means that, for many at the high-end of their professions, work will be their social life; it's where they build the majority of their relationships (albeit superficial and one-dimensional) and where the few friends (or perhaps acquaintances) they have reside. Many extreme professionals prefer to be at work than at home, where they feel alien and unneeded and generally unsettled.

- The shift to knowledge work. In the past it was possible to down tools at the end of a shift and pick up your social life. In the modern corporate world which employs brains not brawn this is no longer the case. And unlike manual labour, knowledge work is never done because there is often no physical product at the end of it

- Globalization. The most successful organizations are those which can attract the best and brightest talent and very often these are the global players who have the necessary complexity required to keep the extreme worker focused, engaged and busy. Addressing the challenges presented by overseeing global operations spanning multiple time zones requires long hours and being on call for 24 hours a day; just what the extreme worker enjoys.

But there is a cost and this can be significant, as a recent survey of extreme workers by the Centre for Work-Life Policy found. The survey found that 45 per cent of executives were extreme workers putting in more than 60 hours a week and meeting five other criteria which included being on call 24 hours a day, facing demands from

\footnotetext{
${ }^{12}$ James, O., (2007), Affluenza, (London: Random House), p 7

${ }^{13}$ Parsons, S., (2007), Children are right to ignore their prescribed futures, The Times, July 5, p 2-7

${ }^{14}$ Hewlett, S., and Buck Luce, C., (2006) Extreme jobs: The dangerous allure of the 70-hour workweek, Harvard Business Review, December, pp 49-60.
} 
several time zones and meeting ever more demanding deadlines. Extreme work takes its toll on workers' health, relationships, marriages and many other aspects of their non-working lives. Issues such as lack of sleep, burnout, depression, lack of exercise, alcohol and substance abuse and marriage breakdown are increasingly common amongst this cohort of the working population ${ }^{15}$.

The extreme position is encapsulated by the $1 / 2 \times 2 \times 3$ formula described by Handy in which there will be half as many people in the core of the company, paid twice as well and producing three times as much ${ }^{16}$. In an increasingly fragmented working world such extreme positions will grow in number as the nature of work continues to favour the winner takes all mode of employment and as more work lower down the organization is commoditized and reduced to little more than machine minding.

However, there is more to staffing than just talent. And despite the current focus on the war for talent, which is of course critical, what is missing is a similar emphasis on those workers who are required to perform the more routine duties and who very often are expected to act as the interface between the business and the customer. As the impact of commoditization reaches deeper into the rank and file of the white collar worker, more and more people will be expected to undertake less demanding and interesting roles. The problem with this is that if the work isn't interesting there is little to keep the employee engaged in the company or its strategies apart from a pay cheque which may be somewhat stagnant and may even be reducing in real terms. The possibility of an unfulfilling working life as part of the many living dead frequenting the workplace is very real and we should all take David Bolchover's view of office existence very seriously ${ }^{17}$. When this happens, staff turnover and absenteeism will undoubtedly increase and levels of motivation and commitment decrease as the swelling ranks of the underemployed lose their work ethic. The problem of course is that this will impact the bottom line, as staff lose their focus on what's important to the organization and what matters to the customer. Therefore it may become difficult to maintain service levels and institutional knowledge. Such problems already beset call centres and the low end service economy jobs, where staff will move to another employer at the drop of the hat especially if it involves more money. They will also be off sick more often and have a poorer attitude to work than their extreme worker colleagues. Instead of working at the top of Maslow's needs hierarchy they work towards the bottom, where the basic needs take on a greater significance. With work holding little or no interest and employers focused on their most talented these workers will move to whoever will pay them the most. Loyalty is lost and the ability to maintain a cohesive and high performing organization becomes increasingly difficult. Organizations that fail to look after their low level employees will lose ground to those that do. What is needed is a renewed interest in these employees and although they may not have the same opportunities as the most talented, they still need to be looked after, challenged, led and motivated. The emergence of a labour war is something to guard against and with an appropriate focus on all employees, not just the cream of the crop, organizations will be able to address the challenges commoditization presents more effectively.

\footnotetext{
${ }^{15}$ Hewlett, S., and Buck Luce, C., (2006) Extreme jobs: The dangerous allure of the 70-hour workweek, Harvard Business Review, December, p 54.

${ }^{16}$ Handy, C., (1994), The empty raincoat, (London: Hutchinson), p 9.

${ }^{17}$ Bolchover, D., (2005) The living dead, (Chichester: Capstone)
} 


\section{Increasing income inequality and its effects}

Work and the workplace have always been unequal. No matter what the pundits, Human Resources or academics might say about meritocracies they rarely exist in their pure form. Whenever an organization is stripped bare, unless it is within government, you will find significant variations in what employees are paid even within the same grade or job role. We are already seeing the highly educated workers pulling further and further ahead and the less educated falling further and further behind, but this hides the true fact that it is only the top ten per cent of the employment pool who are truly excelling and enjoying significant wage gains.

It is clear that income inequality is both rising between skilled workers as much as between the skilled and unskilled cohorts of the workplace ${ }^{18}$. Indeed, inequality is even increasing between those knowledge workers with similar skills and capabilities. As we move towards a high-skill, low wage economy the process through which this happens will not be uniform in that those who find themselves in senior positions and who are able sell their knowledge and insights to global businesses will be highly rewarded, even when those with the same expertise come under the wage pressures familiar with the lower end of the service economy ${ }^{19}$. So whilst many knowledge workers will prosper, many will not. But before we look at impact that such income inequalities have on people and particularly their health, it is worth reiterating why income inequality is likely to increase over the coming years. Stagnating salaries and real drops in income (downward mobility) are very real and are already affecting an increasing number of white collar and professional employees. Companies in response to the threat of commoditization and increased competition are hollowing out as they routinise work and then eliminate it using a combination of technology, outsourcing and offshoring. This trend will undoubtedly continue and as it does so the incomes of those who undertake such work will drop either because the role no longer offers a premium salary (because it requires less skill, is less complex and has been suitably codified to allow others with less knowledge and expertise to perform the work instead) or because they are forced further down the service economy's hierarchy as the good jobs dry up. Increasingly it will be the middle classes who share the economic pain and a few, perhaps no more than 20 per cent of the workforce will continue their upwardly mobile path ${ }^{20}$. As most of the safety nets disappear the future of today's and tomorrow's workers will become increasingly precarious. The other problem that the well educated professional classes have to contend with is the fact that many of the skills they need to excel in today's workplace are increasingly risky investments. Although necessary and often costly to develop they can become obsolete almost overnight as the economy and the job families on which it depends shifts leaving those with outdated skills with few opportunities for applying them elsewhere $^{21}$.

As income distribution bifurcates between the minority who are highly paid and the majority who are not, the impacts of inequality will be more widely felt and especially

\footnotetext{
${ }^{18}$ Hacker, J., (2006), The great risk shift, (Oxford: Oxford University Press), p 64

${ }^{19}$ Brown, P., et al (2006), towards a high-skilled, low-waged economy? A review of global trends in education, employment and the labour market, in Porter, S., and Campbell, M., (eds) Skills and economic performance, (London: Caspian Publishing), p 73

${ }^{20}$ Brown, P., et al (2006), towards a high-skilled, low-waged economy? A review of global trends in education, employment and the labour market, in Porter, S., and Campbell, M., (eds) Skills and economic performance, (London: Caspian Publishing), p 82

${ }^{21}$ Hacker, J., (2006), The great risk shift, (Oxford: Oxford University Press p 75
} 
amongst today's middle and professional classes. What is also interesting about income inequality is that in those countries where it is higher, there tends to be longer working hours ${ }^{22}$. One can only guess this is to make up for lost ground, or to show the boss that you are truly committed to your job. The other point to make here is that growth in countries with high income inequality is slower than in those with lower levels of income inequality ${ }^{23}$. So even from a simple economic standpoint such variations in income seem to inhibit not accelerate economic growth.

The effects of income inequality have been studied for a long time and are well documented. Richard Wilkinson has written extensively on the subject and details the effects in his book, The Impact of Inequality ${ }^{24}$. He found that higher levels of inequality within a society are accompanied by increased levels of mistrust, social exclusion, crime, homicides, insecurity, poor educational attainment, teenage pregnancies, mental illness and many other social, physical and psychological ills. The reverse is true for societies with lower income inequalities who are healthier, happier and generally more stable places to be, with a perfect example of this being Denmark, where income inequality is kept to a minimum through a combination of high marginal tax (which can be as high as 72 per cent for some workers) and high value added tax (at 25 per cent) rates coupled with an effective social economy where everyone is looked after. Once tax has been taken into account the highest paid earns no more than five or six times the lowest and only six per cent of the population live off less than half the average income. ${ }^{25}$ In contrast, the United States and United Kingdom, nations which have some of the highest levels of inequality, have the most trouble with the list above, but so do many of the other capitalist nations; a World Health Organization study into emotional health and income inequality showed that, as one would expect, the United States had the highest incidences of emotional distress than any other market driven country. That said, New Zealand, the United Kingdom, Australia, France, Singapore, and the Netherlands were not far behind ${ }^{26}$.

A good illustration of what could happen as commoditization continues to erode the incomes of the ranks of well paid white collar professions and as the levels of inequality increase between the highly paid extreme workers at one end and the commoditized workers at the other is Russia and Eastern Europe following the changes to communism during the 1970s and 1980s and especially since the collapse of the Soviet Union following the fall of the Berlin Wall in 1989. In the 1960s many of the countries that fell under the Soviet Union's control had better life expectancy than many of the richer countries of the West and this was despite their lower per capita income. This was due to a more even income distribution that relied on a collective system of employment and a centrally driven economy. However when market reforms were introduced during the 1970s and 1980s in response to the unrest in especially Czechoslovakia and Poland, a greater emphasis was placed upon individual economic incentives. As these reforms took hold, the ideals that had previously held the Eastern Bloc together started to unravel, especially when Soviet society became more individualistic. Over time life expectancy dropped as death rates increased dramatically, crime and alcoholism climbed significantly higher and income differentials enlarged appreciably as people could no longer rely on the state to

\footnotetext{
${ }^{22}$ Frank, R., (2007), Falling behind: how rising inequality harms the middle class, (Berkley: University of California Press), p 78

${ }^{23}$ Ibid, p 113

${ }^{24}$ Wilkinson, R., (2005) The impact of inequality, (New York: The New Press)

${ }^{25}$ James, O., (2007) Affluenza, (London: Vermillion), pp 71-74

${ }^{26}$ Ibid., pp 343-346
} 
provide employment or a steady income. ${ }^{27}$ All the social issues identified by Wilkinson surged as inequality increased.

The collapse of the communist regime is a prime example of how an increase in economic individualism not only leads to a widening of income differences but also a rise in the wider problems of society, such as crime, illness and social exclusion. It should come as no surprise that we are already seeing some of these impacts as the early effects of commoditization begin to play out across the industrialised economies of the West. Of course, such changes are not only affecting the West as some of these effects are now being visited on the growing economies of India and China where the gap between the highly paid and the average worker widen. Many amongst the middle and professional classes of the West are finding it difficult to stand still, let alone improve their lot in life and a significant minority have been borrowing against the value of their real estate in an attempt to maintain their lifestyles. Over time we should expect these problems to increase as the winner takes all meets the loser gets none economy. The question is of course, what to do about it. These are macro issues which require national interventions, but in a market economy, governments do not have the appetite to address the problems of those further down the income scale. And because such people lack the skills needed in the workplace they can be easily abused and pushed around; over time a greater number will opt out of the economy and society altogether because they see no future ahead of them. This is especially the case amongst the young. For example, in the United Kingdom there are currently 1.24 million people aged between 15 and 24 who are neither in education, work or a training scheme, a 15 per cent increase since 1997. This sets up a cycle of deprivation that can be near impossible to escape from ${ }^{28}$. Furthermore it is not only those at the bottom of the income scale who will suffer (as they do now), but it will be large numbers of the middle classes who will be finding themselves gradually pushed towards the edges of the economy as their lives become more uncertain and insecure. Unfortunately, the sad truth is that insecure workers tend to under invest in their skills, are more reluctant to change jobs and try to minimise their sense of job commitment to insulate themselves from the psychological loss when the work dries up $^{29}$ which further compounds the problems of inequality.

\section{The emergence of the vicious cycle}

With the backdrop of widening income inequalities and an increasing number of previously well paid employees finding their income falling it is easy to see how commoditization can create a vicious cycle which may be difficult to break.

Figure 2 illustrates this cycle as it affects goods, services and the pay and benefits of the workforce. It is clear that we are now living in a society that expects to purchase goods and services at ever cheaper rates; whatever we buy these days, unless it is overpriced luxury goods or perhaps property, we assume their price will drop year on year whilst expecting the quality to improve. Price deflation is a very real phenomenon and affects a wide range of consumer products. Between 2000 and 2006 price deflation has affected used cars (down 3.6 per cent per year), IT equipment (down 20 per cent per year), photographic equipment (8 per cent per year), clothing (6 per cent per year), toys ( 5 per cent per year) and new cars ( 2 per cent per year $)^{30}$.

\footnotetext{
${ }^{27}$ Wilkinson, R., (2005) The impact of inequality, (New York: The New Press)112-118.

${ }^{28}$ Browne, A., (2006) No school, no job for record numbers, The Times, December 11, pp 1-2

${ }^{29}$ Hacker, J., (2006), The great risk shift, (Oxford: Oxford University Press), p 178

${ }^{30}$ Guthrie, J., (2007) We cheapskates bank on driving a hard bargain, Financial Times, January 7, p 15.
} 
Although such changes are due to the redeployment of Chinese peasants to industrial towns where they are employed as low-waged factory hands and the technological advances of computer technology, this is not the only reason. The Internet is also having an effect through the increasing number of websites which provide price comparisons which has increased transparency and pushed down prices ${ }^{31}$. Stop and think about the wider implications of this?

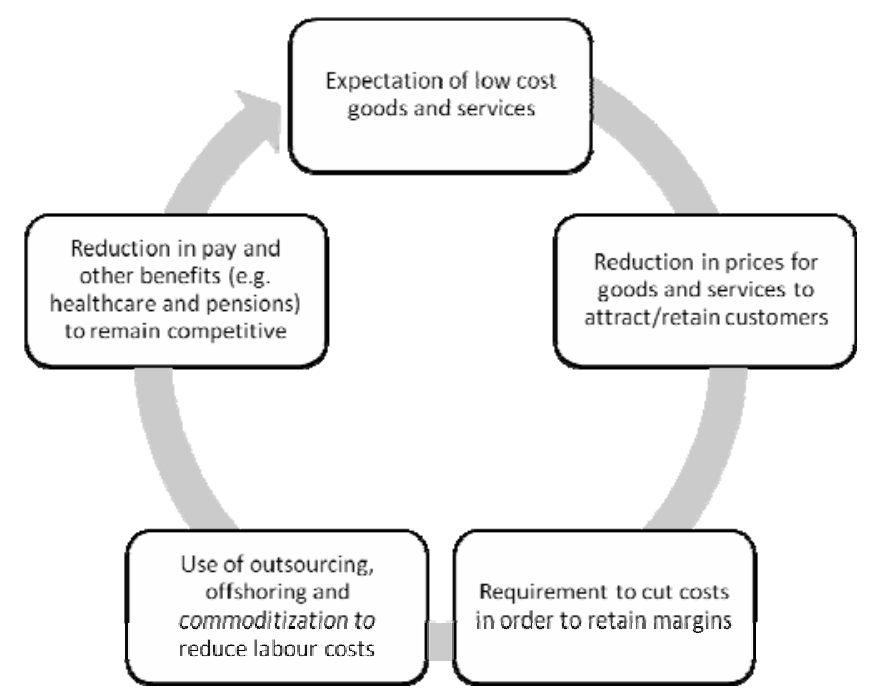

Figure 2 The vicious cycle

As we can see from this simple model, companies which have to reduce their prices (in real terms) in order to attract new customers and retain their existing ones have to recoup their lost margins elsewhere. This is typically achieved in one of three ways: they can increase the productivity of their staff so that they produce more for the same cost, they can create internal efficiencies using a mix of process redesign, technology and restructuring, or they can use outsourcing and offshoring to lock in lower costs and in this way treat their staff as a commodity. Although the first two options are often pursued by most organizations, there is a tendency for the costs to creep back up again, especially if management lacks the cost focused disciplines of the low cost operators. This makes the third option more attractive and once this has been chosen it becomes much simpler to both move additional work overseas and shift where the work is executed as new opportunities to shave their costs and hence improve margins materialise.

Over time the number of organizations exploring and opting for this third option will increase with the continued advances of technology especially in terms of its ability to connect remote workers. This shift to the outsourced and offshored model generates a downward pressure on the pay and benefits of staff because the very threat is enough for people to hold back on their pay demands. There is mounting evidence to suggest that increased volatility in labour demand is leading to moderation in the bargaining power of workers ${ }^{32}$. Many employers are using the threat of offshoring to gain agreement to such reductions which not only include limiting salary increases and reducing pay, but also targeted reductions in headcount and benefits such as pensions.

\footnotetext{
${ }^{31}$ Ibid

${ }^{32}$ OECD (2007), Employment outlook, p 120
} 
Left with limited choices, especially those who lack the transferable skills required to adapt to the changing workplace demands, most will cave in under the pressure; better to have a reduced income than no income at all. We can see this in action with WalMart who drives their Chinese suppliers very hard to produce their products at the lowest possible price (see below). If a supplier is unable to meet the demands made by Wal-Mart, they will lose the business and in such a cut-throat environment, many have no choice but to cut workers' incomes, increase their hours and make them work in sweatshop conditions ${ }^{33}$. With less disposable income employees will expect cheaper goods and services and in the main will have little choice but to seek them out. If retailers and service providers put their prices up, the consumer will hold out for price reductions or find someone else that matches their price expectations which these days will undoubtedly include the Internet. In fact as peoples' incomes go down the demand for cheaper goods and services goes up, which of course adds to the pressure to reduce costs. With the modern economy dependent on the service sector and consumers for its smooth running, it is easy to see how the vicious cycle of figure 2 is perpetuated. Once locked into the cycle it takes a brave company to buck the system and, there are limited options open to you when battling low cost competition. One thing seems to be clear, especially if you listen to commentators such as David Bosshart, author of Cheap ? $^{34}$, and that is that the cycle is here to stay.

A microcosm of what the future may hold is already playing out before our eyes in the shape of Wal-Mart. Although Wal-Mart can be held up as an excellent example of an organization that thrives within the commoditized zone, one of the biggest complaints laid at its door is its unwillingness to pay a living wage to its employees and provide suitable medical cover. For example the Wake up Wal-Mart campaign, funded by the United Food and Commercial Workers Union is aimed at mobilising protests against the retailer in order to force them to begin to pay staff a decent income ${ }^{35}$. In the late 1960s the biggest employer in the United States was General Motors and they paid their staff on average $\$ 29,000$ (in today's terms) together with generous pension contributions, healthcare and other benefits. Today Wal-Mart is the biggest employer and they pay their staff $\$ 17,000$ on average with few if any benefits. When employees are paid near or below the minimum wage, they can only afford to spend their hard earned cash at Wal-Mart or the other retailers who mimic them; they just can't afford to shop elsewhere. Other companies are increasingly finding that they have to follow Wal-Mart's lead in that the benchmark "China price" has to be beaten by those at home if they are to stand any chance of avoiding work going overseas. When you consider that this China price means producing something of between 30 and 50 per cent of what it normally costs, it is easy to see the pressures this creates. Wal-Mart and companies like it exert such extreme pricing pressures on their suppliers that the vicious cycle ends up spilling over into the wider economy as executives of the organizations affected face the stark choices of shrink, close, or move to China ${ }^{36}$. For example, the RCA television plant in Circleville, Ohio, USA had to close because it could no longer supply Wal-Mart with televisions it required at the price expected. Rather than lose all its revenue to other Chinese suppliers, it closed the plant and

\footnotetext{
${ }^{33}$ Ryan, J., (2006) Wal-Mart and China: Boon or bane for American interests, European Business School occasional \& working paper series, no. 3, p 19

${ }^{34}$ Bosshart, D., (2007), Cheap? The real cost of living in a low price, low wage world, (London: Kogan Page)

${ }^{35}$ Birchall, J., (2006) Democrat leaders join fight against Wal-Mart, Financial Times, November 15, p11.

${ }^{36}$ Bianco, A., (2006) The bully of Bentonville, (New York: Currency Doubleday), p 15.
} 
moved its operations to China. The result was a loss of 600 jobs $^{37}$. This hollowing out of the economic heart of communities across the United States and elsewhere is all too common. And as the effects of commoditization spread, the vicious cycle will grip more than just the manufacturers, IT organizations and the back office functions which are currently in the throes of dealing with the impacts this has on their profits, people and futures. The danger of significant portions of the economy ending up locked within this cycle is an increasingly real one.

\section{The temptation of protectionist behaviour - the return to mercantilism}

The transition to an environment where jobs are being increasingly commoditized will be a painful one and will generate significant amounts of noise from pressure groups and political parties alike. Such noise is nothing new as we witnessed similar outbursts in the past from the Luddites in the $19^{\text {th }}$ century who destroyed factory machinery in response to the loss of work; the union workers smashing up Toyotas in Detroit in response to surging Japanese imports and the anti-globalization protestors running amok through Seattle at the 1999 World Trade Organization summit ${ }^{38}$. The noise was tempered by the governments at the time reassuring their citizens that globalization of the manufacturing processes would allow their countries to move into the knowledge economy, where the future employment would be. They were also told that this future was more secure because countries (most notably China) would never be in a position to compete in the knowledge economy; they just didn't have the skills. However, having spent two decades hollowing out the West's manufacturing industry; China now wants to spend the next two moving from "Made in China" to "Invented in China". ${ }^{39}$ In fact China is now only second to the United States when it comes to the amount spent on research and development and in the last decade this has more than doubled as a share of the country's gross domestic product ${ }^{40}$. Multinationals are lining up to establish research capabilities in China where scientists and engineers can undertake the work for only 20 per cent of the labour costs ${ }^{41}$. China is also demonstrating its ability to use its strength in low-cost, low-end manufacturing to expand into the world's most sophisticated high technology businesses. For example, Intel's \$2.5 billion integrated circuit manufacturing plant in the north eastern port city of Dalian has been approved by the Chinese government ${ }^{42}$. This and the many other examples is evidence of how easy China is finding it to transition from a low-wage economy making cheap goods to a high-wage economy (comparatively so) producing valuable ones ${ }^{43}$.

So now that knowledge work is also being offshored, these promises look somewhat empty and people are becoming uneasy about their employability once more. As the noise gets louder the potential for protectionist behaviour to increase in order to stem the reduction in income and loss of jobs overseas is highly likely and may be politically necessary for the administrations in power if they are to retain popular support. For example as the Democrats become increasingly optimistic about winning

\footnotetext{
${ }^{37}$ Ryan, J., (2006) Wal-Mart and China: Boon or bane for American interests, European Business School occasional \& working paper series, no. 3, p 19

${ }^{38}$ Lynch, D., (2006), Election pushes globalization to forefront, USA Today, Money Section B, p 1B

${ }^{39}$ Dyer, G., (2007) The dragon's lab - how China is rising through the innovation ranks, Financial Times, January

5, p 13.

${ }^{40}$ Ibid

${ }^{41}$ Ibid

${ }^{42}$ Batson, A., (2007) China shifts towards higher-end production, The Wall Street Journal, March 23-25, p 4

${ }^{43}$ Ibid
} 
the 2008 United States election especially on the back of seizing the House of Representatives and the House of Senate in the 2006 mid-term elections, they are beginning to play the protectionist card. Some amongst their ranks are calling for the renegotiation of the North American Free Trade Agreement (NAFTA) and trade ties with China to ensure they include protection for United States labour ${ }^{44}$. There are also increasing calls to limit the offshoring of American jobs and several states have passed laws that prohibit the export of public sector jobs. In addition, the Senate passed a law in 2004 which prevents private sector companies from using offshore workers in order to compete against government workers when bidding for new contracts $^{45}$. Similar views are emerging within the European Union, where it is now recognised that the comparative advantage associated with the knowledge economy is beginning to unravel as China and India continue to develop their expertise in the high-skilled, high-tech sectors. ${ }^{46}$ Even amongst the typically pro-globalization community of industrialists and bankers in the United Kingdom there are those who are beginning to question the commitment to open markets, especially in light of the increasing number of British companies falling into foreign ownership. The same is true in Italy where the Italian motorway group Autostrade called off its merger with Spain's Albertis after intense political pressure ${ }^{47}$. Ben Bernanke, chairman of the Federal Reserve recently commented when addressing an audience on the history of economic integration, "the social and political opposition to openness can be strong. Although this opposition has many sources...much of it arises because changes in the patterns of production are likely to threaten the livelihoods of some workers and the profits of some firms, even when these changes lead to greater productivity and output overall." 48 These words may not reassure the increasing numbers of middle and professional class employees who will be looking to their governments to provide them with some protection against the onslaught of white collar commoditization. If governments are unwilling to provide a suitable safety net through the subsidising of retraining or unemployment benefit then the electorate will expect them to look towards protectionist barriers which will allow them as much as possible to maintain their current lifestyles and economic longevity. For example United States politicians are currently trying to block Evraz a Russian steel company from buying a small US based rival $^{49}$. It is likely that the calls for the World Trade Organization to abandon its emphasis on forcing open global markets will increase as the full costs of globalization are felt amongst the West's middle classes. So could we see a return to Mercantilism which dominated European trade between 1550 and 1750? During this period protectionist measures, which included trade tariffs, were used to ensure a country maintained a trade surplus by exporting more than it imported. Only time will tell. However, the past suggests that when the political price of free trade outweighs

\footnotetext{
${ }^{44}$ Lynch, D., (2006), Election pushes globalization to forefront, USA Today, Money Section B, p B2

${ }^{45}$ Brown, P., et al (2006) Towards a high-skilled, low-waged economy? A review of global trends in education, employment and the labour market, in Porter, S., and Campbell, M., (eds) Skills and economic performance, (London: Caspian Publishing), p 86

${ }^{46}$ Lucas, C., and Hines, C., (2005) Europe’s hi-tech future: the last colonial delusion, provided to the author through private correspondence

${ }^{47}$ Nixon, S., (2006) Why we must resist the coming counter-revolution, Money Week, 15 December, p18.

${ }^{48}$ Wolf, M., (2006), We must act to share the gains with globalisation's losers, Financial Times, September 6, p 23.

${ }^{49}$ Nixon, S., (2006) Why we must resist the coming counter-revolution, Money Week, 15 December, p18.
} 
the economic benefits powerful nations will seek to protect their markets, companies and employees from overseas competition ${ }^{50}$.

But is there any point in trying to protect inefficient business models because in the end it costs the nations dear because taxes have to rise or be redirected to fund the subsidies required to allow the businesses and individuals affected by commoditization to remain viable.

\section{The end game}

The combination of demographic change, immigration, technological advancements, the availability of an increasing number of graduate level workers and the resurgence of China and India are forcing companies to consider the impacts of commoditization on their operations and markets and respond accordingly. The choices are not necessarily straightforward, but there are choices all the same. Whether to pursue a path focused on innovation, or one which tackles the cost issues associated with commoditization head-on or a combination of both is a decision that needs to be made in the boards of every corporation. The pressure to simplify, standardize and ultimately eliminate unnecessary work out of the system will increase as those organizations who manage to address the challenges will add to the competitive forces and make those companies that fail to respond increasingly untenable. It is also clear that the process of commoditization will continue for some time to come and may well accelerate as the Boomer Generation finally leaves the workplace. What the end game will look like is a little more difficult to predict, but like so many changes that have affected the workplace and society in the past, there will be winners and losers, although on this occasion the losers may well outnumber the winners by a wide margin. Sitting on the sidelines and watching the commoditization juggernaut steam towards you may not be the best strategy, but many will have little choice but to watch and wait for the inevitable collision.

\footnotetext{
${ }^{50}$ Brown, P., et al (2006) Towards a high-skilled, low-waged economy? A review of global trends in education, employment and the labour market, in Porter, S., and Campbell, M., (eds) Skills and economic performance, (London: Caspian Publishing), p 87
} 